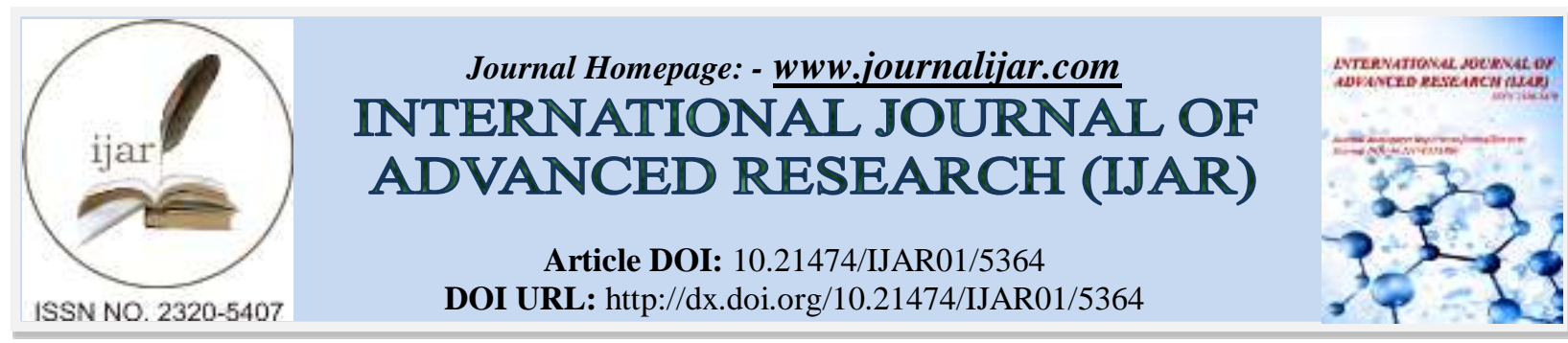

RESEARCH ARTICLE

\title{
KANCHNAR (BAUHINIA VARIEGATA) AS A MEDICINAL HERB: A SYSTEMATIC REVIEW.
}

\section{Vikas Nariyal ${ }^{1}$ and Priyanka Sharma ${ }^{2}$.}

1. Research Officer (Ayu.), Regional Ayurveda Research Institute for Nutritional Disorders, CCRAS, Ministry of AYUSH, Mandi, HP.

2. Ph.D. Scholar, Dept. of Stree \& Prasuti Tantra, National Institute of Ayurveda, Jaipur, Rajasthan.

\section{Manuscript Info}

Manuscript History

Received: 08 July 2017

Final Accepted: 10 August 2017

Published: September 2017

Key words:-

Bauhinia variegata, Kanchnar.

\begin{abstract}
Bauhinia variegata (Kachnar), a medicinal tree native to temperate and tropical Indian subcontinent is well practiced in Indian indigenous health science; Ayurveda. Kachnar bark is used in disorders like Gandamala (Lymphadenopathy), Galaganda (Goitre), Arbuda (Tumor), Ashthila (BPH) and Kapha-Pitta dosha disorders while flowers have Pittaghna (Pacify pitta dosha), Rakta Pradaraghna (Cures Dysfunctional Uterine Bleeding), Kaasghna (Curing cough) and Kshyaghna (Anti tubercular) properties. In some parts of country (Himachal Pradesh, Northeast States), its buds and flowers are used as vegetable and various dishes like chutney and pickles. Accounting above said benefits, authors decided to review systematically the published researches on Kanchnar. A "Pubmed" search using key word "Bauhinia variegata" results a total of 72 citations. Results were dispersed, ranging from animal studies for medicinal properties to its use as a potential bio-resource for stable, reproducible nanoparticle. Studies demonstrated antidiabetic, anti-oxidant, analgesic, anti-dyslipidemia, anti-inflammatory, anti-microbial, cytotoxic and many more properties of B. variegata other than its conventional use. Studies supported, demonstrated and opens a way for further evaluation of medicinal properties of $\mathrm{B}$. variegata as an herbal medicine.
\end{abstract}

Copy Right, IJAR, 2017,. All rights reserved.

\section{Background:-}

B. variegata is native to temperate and tropical Indian Sub-continent (i.e. India, Bhutan, Nepal and Pakistan), Southeastern Asia (i.e. Laos, Myanmar, Vietnam and Thailand) and China. It is a deciduous tree, up to $15 \mathrm{~m}$ tall with dark brownish bark, nearly smooth; branches gray puberulent when young, later glabrous. Petiole 2.5-3.5 cm; leaf blade suborbicular or broadly ovate, 5-9 $\times 7-11 \mathrm{~cm}$. Apex bifid to 1/3, lobes rounded at apex. Flower buds fusi-form, smooth, subsessile. Petals white, or with pink or purplish spots, obovate or oblanceolate, 4-5 cm, clawed. Kanchnar is well described in ancient Indian science of life known as Ayurveda and its Stem bark \& flowers are used as medicine in various formulations. Kachnar bark is used in disorders like Gandamala (Lymphadenopathy), Galaganda (Goitre), Arbuda (Tumor), Ashthila (BPH) and Kapha-Pitta dosha disorders while flowers have Pittaghna (Pacify pitta dosha), Rakta Pradaraghna (Cures Dysfunctional Uterine Bleeding), Kaasghna (Curing cough) and Kshyaghna (Anti tubercular) properties. However, it is also practiced in treatment of various carcinoma. Kachnar (Bauhinia variegata) is well known tree species to the people of Himachal Pradesh. In the month of March and

Corresponding Author:- Vikas Nariyal.

Address:- Research Officer (Ayu.), Regional Ayurveda Research Institute for Nutritional Disorders, 587 
April, buds of Kachnar are cooked and eaten as a delicious food called "Karalen Ki Sabji". People practice to eat Kachnar buds (locally called Karalen) seasonally when available with the celebration and happiness. Eating Kachnar buds as Vegetable is also practiced in Northeastern part of the country. A systematic review on medicinal use of Kanchnar was missing despite of its wide use in Ayurveda and cultural importance. So, this article was formulated.

\section{Methods:-}

Search engine "PubMed" database of references and abstracts on life sciences and biomedical topics was used using the key word "Bauhinia variegata" identified a total of 72 citations including in-vivo, in-vitro and survey studies. Citations between 1975 to Apr-2017 were included in review. These citations were examined and studies demonstrating new emerging aspects of medicinal properties of Bauhinia variegata were included in present review.

\section{Review Results:-}

Anti-Diabetic Activity:-

Aqueous Extract of B.Variegata leaves in animal models of T-I \& T-II Diabetes Mellitus on oral administration for the duration of 28 days shown significant reduction in Plasma Glucose levels ${ }^{\mathrm{i}}$. It also reduces cholesterol, Triglycerides, Sr. Creatinine, Blood Urea in both types ${ }^{1}$. Histopathological, Aqueous Extract decrease necrotic changes in pancreatic tissue. Study by Mohamed A. Farag demonstrated $\alpha$-Glucosidase ${ }^{\text {ii }}$ inhibitory effect of leaf extract.

The crude ethanolic extract of leaves of B. variegata L. var. Candida Void and its major metabolite (6 S,7 E,9 R)-9hydroxymegastigma-4,7-dien-3-one-9- beta-glycopyraroside (roseoside) were shown to increase insulin secretion ${ }^{\text {iii, iv }}$ from insulin-secreting cell line INS-1 in a dose-dependant manner.

\section{Anti-Microbial, ${ }^{\mathrm{v}, \text { vi }}$ Activity:-}

The antibacterial activities of the extracts derived from leaves of B. variegata against four Gram-negative pathogenic bacteria, namely, K. pneumoniae, Proteus spp., E. coli, and Pseudomonas spp. Proteus spp., E. coli and Pseudomonas spp. exhibited total resistance to nonpolar extracts [PE (petroleum ether), BZ (benzene), $\mathrm{CH}$ (chloroform), and EA (ethyl acetate) extracts] at test concentration. However, low to moderate inhibitory efficacy was recorded in polar fractions [AC (acetone), ET (ethyl alcohol), and AQ (water) extracts] against previously mentioned bacteria. $\mathrm{PE}$ and $\mathrm{CH}$ extracts derived from leaves exhibited activity against $K$. pneumoniae.

In Staphylococcus aureus induced Mastitis ${ }^{\mathrm{vii}}$ in Goats, B. variegata bark powder administration shows antibacterial, bio enhancing and anti-inflammatory properties. Animals also exhibited marked reduction in polymorphonuclear cells and fibrous tissue indicating antifibrotic property of B. variegata $\mathrm{L}$.

Lectins are carbohydrate-binding proteins that specifically and reversibly interact with different types of carbohydrates and glycoproteins. B. variegata Lectin significantly reduced early adhesion of Step. mutans and Strep. Sanguis to a saliva-coated surface.

\section{Chelation Action ${ }^{\text {viii:- }}$}

Dose dependent effect was observed in metal ion chelating ability of the extracts of different concentrations. Polar extracts of $B$. variegata showed better activity as compared with nonpolar extracts. The decreasing order of chelating activity of extracts was AC, AQ, ET, BZ, CH, PE, and EA.

(AC: acetone, AQ: water, ET: ethyl alcohol, BZ: benzene, $\mathrm{CH}$ : chloroform, PE: petroleum ether and EA: ethyl acetate.)

\section{Cytotoxic Activity:-}

Cytotoxic $^{\text {ix }}$ effect of B. variegata leaf extracts against cancer cell lines using SRB (Sulforhodamine B Dye) assay. $\mathrm{AQ}$ fraction of B. variegata was found to be the most active exhibiting \% growth inhibition of DU-145 (prostate = 99\% inhibition), HOP-62 (lung $=87 \%$ inhibition), IGR-OV-1 (ovary $=99 \%$ inhibition), MCF-7 (breast $=93 \%$ inhibition), and THP-1 (leukemia $=94 \%$ inhibition) cancer cell lines, at $100 \mu \mathrm{g} / \mathrm{mL}$ concentration of extract.

Study by Agarwal \& Pandey ${ }^{\mathrm{x}}$ demonstrated anticarcinogenic activity of 50\% methanolic extract of Kachanar leaves using two stage protocol in skin papilloma model in Swiss albino mice and melanoma model in C57 Bl tumour 
bearing mice. Significant prevention of papilloma development, delay in the first appearance of papilloma and reduction in cumulative no. of papilloma was observed in the DMBA + Kachanar + Croton treated group of male swiss Albino mice. In melanoma model in C57 Bl tumour bearing mice experiment, Kachnar leaves $50 \%$ methanolic extract shown increase in life span of animals and significant reduction in tumour size. The tumour volume was significantly reduced (in dose dependent manner). Single application of Bauhinia extract 24 hours prior the intraperitoneal administration of Cyclophosphamide has significantly prevented the micronucleus formations and chromosomal aberrations in dose dependent manner in bone marrow cells of mice, which demonstrated antimutagenicity activity of Bauhinia Variegata.

\section{Antioxidant ${ }^{x i}$ Activity:-}

Ethanolic and aqueous extracts of the stem bark and root of B. variegata Linn. were assessed for in vitro antioxidant activity by various methods namely total reducing power, scavenging of various free radicals such as 1,2-diphenyl2-picrylhydrazyl (DPPH), super oxide, nitric oxide, and hydrogen peroxide; significant antioxidant activity was observed in all the methods.

\section{Neural Activity:-}

Acetylcholinesterase inhibition activity ${ }^{x i i}$ was analyzed through Thin Layer Chromatography (TLC). Enzyme inhibition was observed mainly in flowers. However, inhibition found in lower intensity on branches and leaves showed no inhibition at all.

\section{Nephroprotective ${ }^{\text {xiii }}$ Activity:-}

In vivo cisplatin-induced nephropathy in rats when administered whole stem ethanol extract of BV for the duration of 14 days, attenuated the biochemical and histological signs of nephrotoxicity of cisplatin in a dose-dependent fashion. Decrease in Serum level of creatinine $\&$ urea and Increase in urine output $\&$ body weight was observed ${ }^{\text {xiv }}$.

\section{Anti-inflammatory \& Analgesic Activity:-}

New Triterpene Saponin (Compound 9) from Bauhinia variegata leaves reduces edema accompanied by significant reduction in $\mathrm{PGE}_{2}$ (Prostaglandin $\mathrm{E}_{2}$ ) level in serum, liver homogenate and granuloma. Reduction in hepatic and pulmonary granuloma diameter was observed after treatment with compound 9 was suggested may be due to its antiinflammatory $^{\mathrm{xv}}$ activity. Furthermore, compound 9 shown Analgesic effects both in visceral and central nociceptive ${ }^{\mathrm{xvi}}$ mouse models.

\section{Hypolipidaemic ${ }^{\text {xvii }}$ Activity:-}

Ethanolic and aqueous extracts of the stem bark and root of B. variegata Linn. effectively decreases plasma cholesterol, triglyceride, LDL, and VLDL and increases plasma HDL levels in Triton WR-1339 (iso-octyl polyoxyethylene phenol) induced hyperlipidemic albino rat.

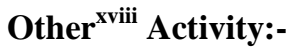

A study proves that B. variegata is a potential bio-resource for stable, reproducible nanoparticle synthesis and may be proposed as an efficient mosquito control agent.

\section{Discussion:-}

In Ayurveda, Kachnar conventionally practiced in Arbuda, Galaganda, Ashthila and Kapha-Meda dominant diseases or disorders. A close resemblance of galaganda with goiter and ashthila with BPH has lead wide spread use of Kachnar in above said conditions. Apart from conventional medicinal use of B. variegata L. we see scientist and researchers throughout the world exploring new medical aspect of B. variegata L. Present time is a transition phase where trend of medicine is shifting from artificial chemicals to natural origin. As a result of it we see various studies exploring new medicinal properties of B.V.

Studies demonstrates that BV have anti-diabetic, anti-dyslipidemia and nephroprotective properties. Ideally above said properties make BV beneficial in condition of Diabetic Nephropathy or diabetics with dyslipidemia.

In era where various pathogens are resistant or attaining resistance to antibiotics. BV can be used as an adjunct or alternate medicine against various bacterial pathogens. 
Chelating property for ferrous ions should be studied in animal models. This property could be beneficial in conditions of iron overload like hemochromatosis. It also opens door for possibilities of chelating activity for various other metal ions.

Cancer in Ayurveda is treated on the line of Arbuda. Animal studies and in-vitro cytotoxic activity of B.V using cancer cell lining study on BV leaf extracts actively inhibits various cancer cell linings demonstrating its anticarcinogenic and anti-mutagenic potential. We are well aware of common side effects of conventional chemotherapy for cancers, an alternative to it will be beneficial to the patients.

Alzheimer's disease is related mainly due to decrease in Acetylcholine in synaptic cleft. Various cholinomimetic therapies have been tested for the treatment of Alzheimer's disease. In-vitro study on Acetylcholinesterase (AChE) inhibition, observed maximum in flowers, open another dimension for medicinal use of BV.

\section{Conclusion:-}

Today is an era, where we expect long life expectancy due to better and advancement of medical knowledge and their management. But we also dealing with new emerging problems like drug resistance to various microbes, sprouts of epidemics like EBOLA, H1N1 etc. Since time immortal we have been nurtured by mother nature, providing herbs and food for our care. People worldwide looking for a competent and alternative system to combat emerging human health issues. Bauhinia variegata could give answers to many problems we facing now days. Various researches give proof that Kanchnar (Bauhinia variegata) have potential to be evaluated further for its medicinal properties.

\section{Reference:-}

1. Kulkarni YA, Garud MS. Bauhinia variegata (Caesalpiniaceae) leaf extract: An effective treatment option in type I and type II diabetes. Biomed Pharmacother. 2016 Oct;83:122-129.

2. Farag MA, Sakna ST, El-Fiky NM, Shabana MM, Wessjohann LA. Phytochemical, antioxidant and antidiabetic evaluation of eight Bauhinia L. species from Egypt using UHPLC-PDA-qTOF-MS and chemometrics. Phytochemistry. 2015 Nov;119:41-50.

3. Frankish N, de Sousa Menezes F, Mills C, Sheridan H. Enhancement of insulin release from the beta-cell line INS-1 by an ethanolic extract of Bauhinia variegata and its major constituent roseoside. Planta Med. 2010 Jul;76(10):995-7.

4. Hussain Z, Waheed A, Qureshi RA, Burdi DK, Verspohl EJ, Khan N, et al. The effect of medicinal plants of Islamabad and Murree region of Pakistan on insulin secretion from INS-1 cells. Phytother Res. 2004 Jan;18(1):73-7.

5. Mishra A, Sharma AK, Kumar S, Saxena AK, Pandey AK. Bauhinia variegata leaf extracts exhibit considerable antibacterial, antioxidant, and anticancer activities. Biomed Res Int. 2013;2013:915436.

6. Mishra A, Kumar S, Bhargava A, Sharma B, Pandey AK. Studies on in vitro antioxidant and antistaphylococcal activities of some important medicinal plants. Cell Mol Biol. 2011 Feb 12;57(1):16-25.

7. Dash JR, Sar TK, Samanta I, Pal S, Khan M, Patra NC, et al. Efficacy evaluation of Bauhinia variegata L. stem bark powder as adjunct therapy in chronic Staphylococcus aureus mastitis in goat. Pharmacogn Mag. 2014 Aug;10(3):S512-8.

8. Mishra A, Sharma AK, Kumar S, Saxena AK, Pandey AK. Bauhinia variegata leaf extracts exhibit considerable antibacterial, antioxidant, and anticancer activities. Biomed Res Int. 2013;2013:915436.

9. Mishra A, Sharma AK, Kumar S, Saxena AK, Pandey AK. Bauhinia variegata leaf extracts exhibit considerable antibacterial, antioxidant, and anticancer activities. Biomed Res Int. 2013;2013:915436.

10. Agrawal RC, Pandey S. Evaluation of anticarcinogenic and antimutagenic potential of Bauhinia variegata extract in Swiss albino mice. Asian Pac J Cancer Prev. 2009;10(5):913-6.

11. Rajani GP, Ashok P. In vitro antioxidant and antihyperlipidemic activities of Bauhinia variegata Linn. Indian J Pharmacol. 2009 Oct;41(5):227-32.

12. Kamilla Monteiro dos Santos, Priscila Sant'Ana Gonçalves, Maria José Nunes de Paiva, Guilherme Araújo Lacerda. Acetylcholinesterase inhibition starting from extracts of Bauhinia variegata L., Bauhinia var. candida (Aiton) Buch.-Ham., and Bauhinia ungulata L. Rev. Soc. Bras. Med. Trop. 2011Dec;44(6):781-83

13. Agarwal K, Varma R. Ethnobotanical study of antilithic plants of Bhopal district. J Ethnopharmacol. 2015 Nov 4;174:17-24. 
14. Pani SR, Mishra S, Sahoo S, Panda PK. Nephroprotective effect of Bauhinia variegata (Linn.) whole stem extract against cisplatin-induced nephropathy in rats. Indian J Pharmacol. 2011 Apr;43(2):200-2.

15. Mohamed MA, Mammoud MR, Hayen H. Evaluation of antinociceptive and anti-inflammatory activities of a new triterpene saponin from Bauhinia variegata leaves. Z Naturforsch C. 2009 Nov-Dec;64(11-12):798-808.

16. Mohamed MA, Mammoud MR, Hayen H. Evaluation of antinociceptive and anti-inflammatory activities of a new triterpene saponin from Bauhinia variegata leaves. Z Naturforsch C. 2009 Nov-Dec;64(11-12):798-808.

17. Rajani GP, Ashok P. In vitro antioxidant and antihyperlipidemic activities of Bauhinia variegata Linn. Indian J Pharmacol. 2009 Oct;41(5):227-32.

18. Govindarajan M, Rajeswary M, Veerakumar K, Muthukumaran U, Hoti SL, Mehlhorn H, et al. Novel synthesis of silver nanoparticles using Bauhinia variegata: a recent eco-friendly approach for mosquito control. Parasitol Res. 2016 Feb;115(2):723-33. 